\title{
Title:
}

\section{Giant gastric lipoma as an uncommon cause of upper gastrointestinal bleeding}

\section{Authors:}

Diego Rosales , Pedro Montes

DOI: $10.17235 /$ reed.2021.8210/2021

Link: PubMed (Epub ahead of print)

Please cite this article as:

Rosales Diego, Montes Pedro. Giant gastric lipoma as an uncommon cause of upper gastrointestinal bleeding. Rev Esp Enferm Dig 2021. doi: 10.17235/reed.2021.8210/2021.

This is a PDF file of an unedited manuscript that has been accepted for publication. As a service to our customers we are providing this early version of the manuscript. The manuscript will undergo copyediting, typesetting, and review of the resulting proof before it is published in its final form. Please note that during the production process errors may be discovered which could affect the content, and all legal disclaimers that apply to the journal pertain. 


\section{Giant gastric lipoma as an uncommon cause of upper gastrointestinal bleeding}

Diego Rosales 1, Pedro Montes 2

1. Gastroenterology Unit. Hospital de Emergencia Ate Vitarte. Lima, Peru

2. Gastroenterology Unit. Hospital Nacional Daniel Alcides Carrión. Callao, Peru

Author for correspondence: diegor_11@hotmail.com

Conflicts of interest statement: the authors declare no conflicts of interest.

Funding statement: no funding sources to declare.

Informed consent was obtained.

A 52-year-old male patient presented at the emergency room for melena. A gastroscopy was performed, which revealed a submucosal lesion in the antrum of the stomach. The lesion was lined with regular smooth mucosa except for an apical ulceration (Figure A). Histology demonstrated gastric mucosa with foveolar hyperplasia. Abdominal computerized tomography showed a homogeneous, well-delimited fat-density mass measuring $5.9 \times 4.3 \mathrm{~cm}$ (Figure B). Laparoscopic surgery then found a solid tumor involving the whole thickness of the anterior wall at the prepyloric area, which was resected. Microscopic examination revealed a homogeneous, soft, ulcerated submucosal mass of yellowish adipose tissue that was $5 \times 5 \times 2 \mathrm{~cm}$ in size. Microscopically, the tumor was composed of mature fatty tissue with fibrous septa, and was partially encapsulated and circumscribed. It was reported as submucosal lipoma. The patient had a favorable outcome.

Lipomas are slow-growing benign tumors composed of adipose tissue that are unusually found in the gastrointestinal tract. They are more common in the colon, with gastric lipomas representing only $5 \%$ of all gastrointestinal lipomas (1,2). Giant gastric lipomas (> 
$4 \mathrm{~cm}$ ) are even rarer (3). While most cases are asymptomatic, these lesions may be increasingly associated with abdominal pain, dyspepsia, obstruction, intussusception, and bleeding as size goes up (3).

On CT scans gastric lipomas appear as homogeneous, well-circumscribed, fat-density areas with attenuation between -70 and $-120 \mathrm{HU}$. CT has demonstrated high sensitivity and specificity for their diagnosis, hence it is considered a first-line approach when suspicion arises (4). Management is usually surgical with partial gastrectomy and enucleation, although endoscopic management may be considered for some patients depending on tumor size (5).

\section{REFERENCES}

1. Almohsin M, Meshikhes AW. Gastric lipoma presenting with haematemesis. BMJ Case Rep. 2015 Jan 29;2015:bcr2014206884.

2. Nasa M, Choksey A, Phadke A, et al. Gastric lipoma: an unusual cause of dyspeptic symptoms. BMJ Case Rep. 2016 Jun 22;2016:bcr2016215297.

3. Cappell MS, Stevens CE, Amin M. Systematic review of giant gastric lipomas reported since 1980 and report of two new cases in a review of 117110 esophagogastroduodenoscopies. World J Gastroenterol. 2017 Aug 14;23(30):5619-5633.

4. Sullivan IW, Hota P, Dass C. Gastric lipomas: a case series and review of a rare tumor. BJR Case Rep. 2019 Jan 16;5(2):20180109.

5. Amundson JR, Straus D, Azab B,et al. Giant symptomatic gastric lipoma: A case report and literature review. Int J Surg Case Rep. 2018;51:313-317. 


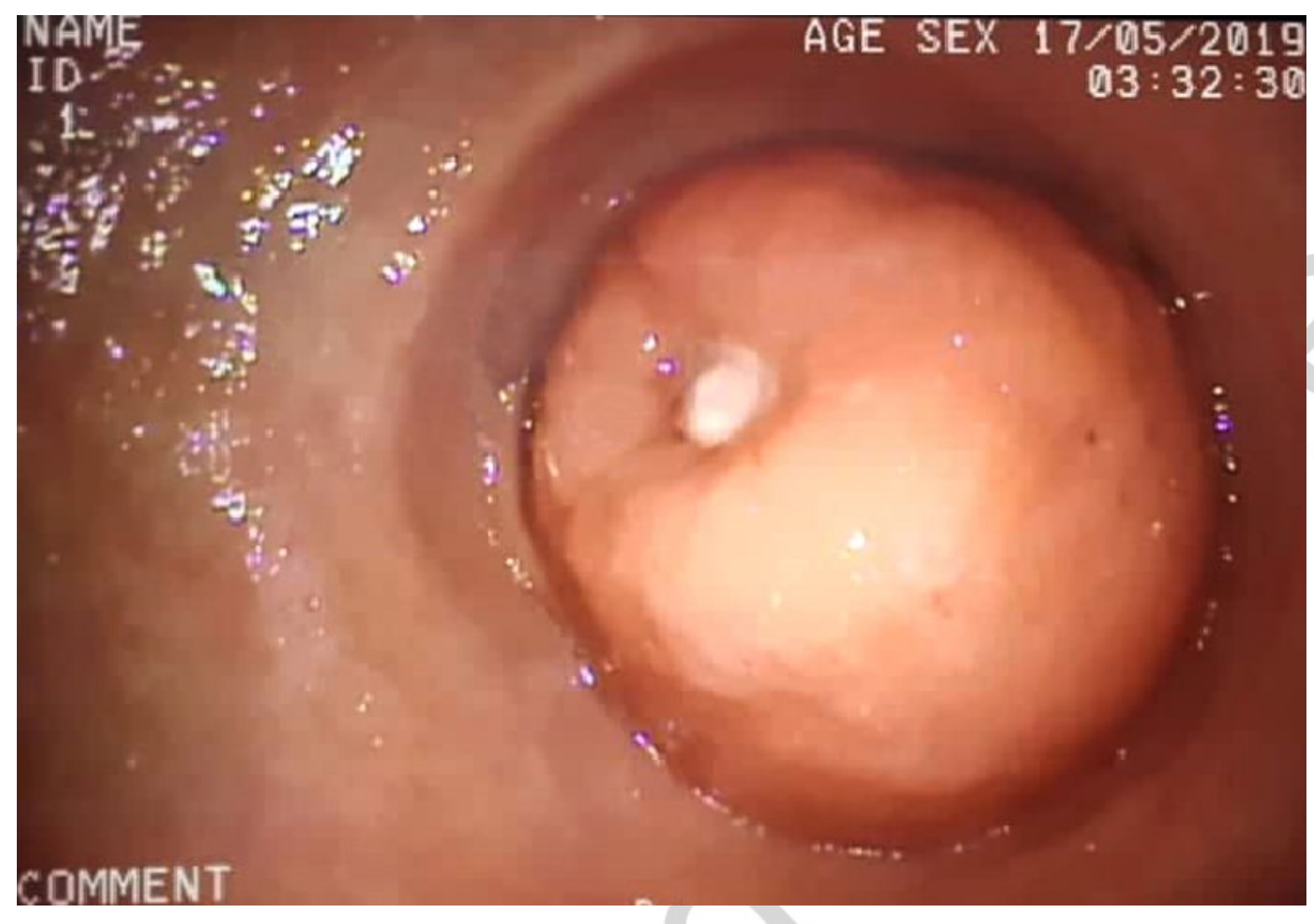

Figure A: Gastroscopy: submucosal lesion with apical ulceration in the antrum of the stomach. 


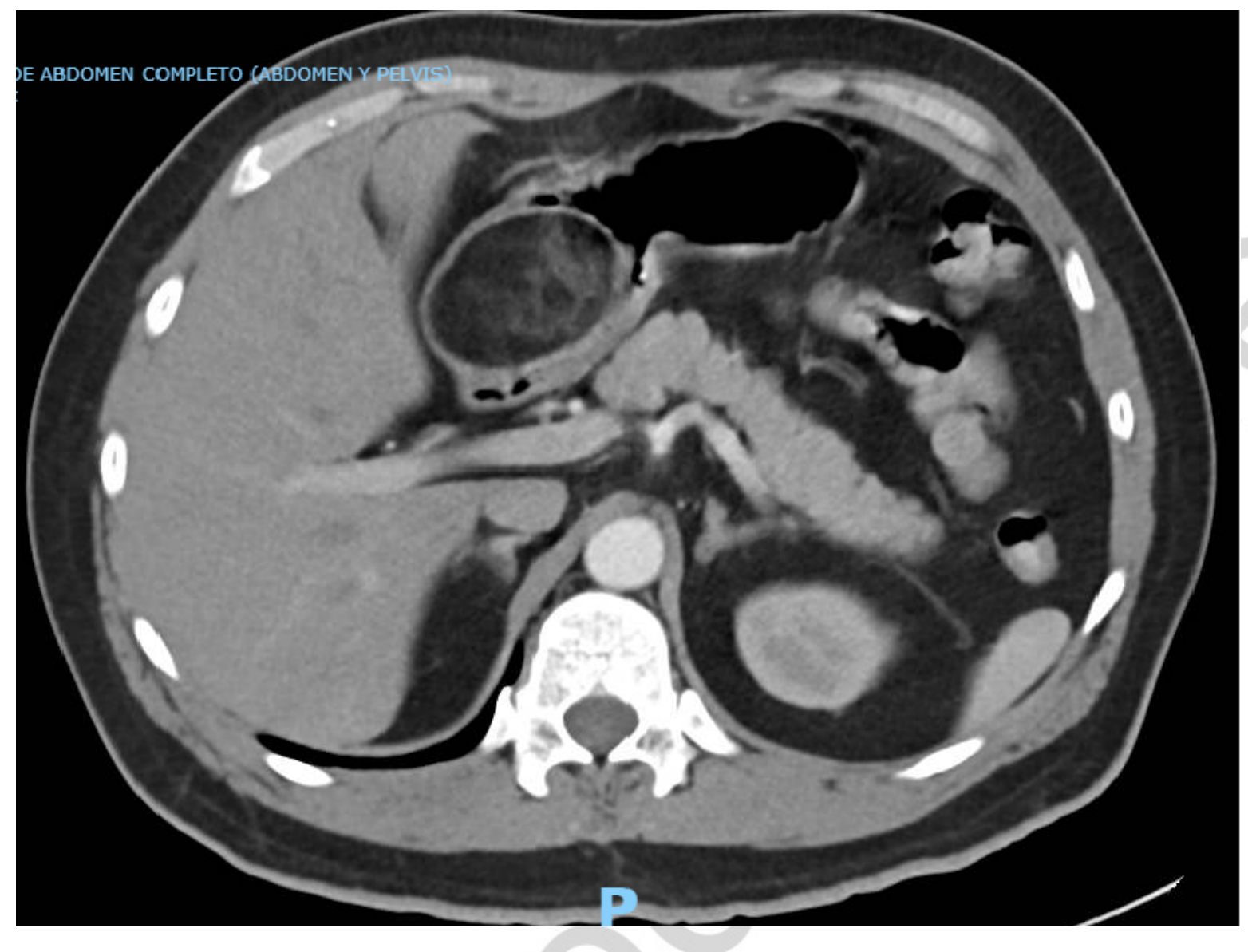

Figure B: Abdominal CT: a homogeneous, well-delimited fat-density mass measuring 5.9 x $4.3 \mathrm{~cm}$ in the gastric antrum. 